\title{
Feeding grounds for waders in the Bay of the Mont Saint-Michel (France): the Lanice conchilega reef serves as an oasis in the tidal flats
}

\author{
Bart De Smet ${ }^{1,{ }^{*}}$, Laurent Godet ${ }^{2}$, Jérôme Fournier ${ }^{3,4}$, Nicolas Desroy $^{5}$, Mikaël Jaffré ${ }^{6}$, Magda Vincx ${ }^{1}$, \\ Marijn Rabaut ${ }^{1}$
}

\footnotetext{
${ }^{1}$ Department of Biology, Marine Biology Section, Ghent University, Krijgslaan 281/S8, 9000, Ghent, Belgium

2 CNRS, UMR 6554 LETG-Nantes Géolittomer, Université de Nantes, B.P. 81227, 44312, Nantes Cedex 3 , France

${ }^{3}$ CNRS, UMR 7208 BOREA, Muséum National d'Histoire Naturelle, 7 Rue Cuvier, CP 32, 75231, Paris Cedex 05, France

${ }^{4}$ Station Marine de Dinard, USM 404 Muséum National d'Histoire Naturelle, 38 Rue du Port Blanc, 35800, Dinard, France

5 IFREMER Laboratoire Environnement et Ressources FBN, CRESCO, 38 Rue du Port Blanc, 35800, Dinard, France

${ }^{6}$ Université de Lille 1, UMR 8187 LOG, Station Marine de Wimereux, 28 Avenue Foch, 62930, Wimereux, France
}

*: Corresponding author : Bart De Smet, tel.: +32 (0)9 2648534 ; Fax: +32 (0)9 2648598 ;

email address : badsmet.desmet@ugent.be

\begin{abstract}
:
The tube-building polychaete Lanice conchilega can form dense populations, often called reefs, which promote benthic community change and constitute feeding grounds for secondary consumers. The aim of this study was to quantify the role of the L. conchilega reef of the Bay of the Mont Saint-Michel (BMSM) for feeding waders, by combining macrobenthos data, bird counts and bird diet information. Wader densities in the reef were on average 46.6 times higher than in non-reef areas. According to faecal analyses, waders in the reef mainly selected the accompanying fauna and especially crustaceans. The attractiveness of the reef to feeding birds may be largely explained by the high abundance, richness and biomass of macrobenthic species in the reef compared with the rest of the BMSM.
\end{abstract}




\section{Introduction}

Lanice conchilega is a widespread tubicolous polychaete that can form dense aggregations, considered biogenic reefs (Rabaut et al. 2009; Callaway et al. 2010). Above particular density thresholds, the structures of the tubes as well as the biological activity of the "engineer species" (Callaway 2006; Godet et al. 2008), generate specific sedimentological "structures" (Carey 1987; Feral 1989) and enhance the species diversity and abundance of the associated benthic macrofauna by stabilizing the sediments (Zühlke 2001; Callaway 2006; Rabaut et al. 2007; Van Hoey et al. 2008). These reefs are also important feeding grounds for flatfishes, particularly the juveniles of Pleuronectes platessa (Rijnsdorp and Vingerhoed 2001; Rabaut et al. 2010).

Lanice conchilega can be an important item in the diet of several waders (Goss-Custard and Jones 1976; Yates et al. 1993). Godet et al. (2009) showed that oystercatchers may significantly select $L$. conchilega reefs to feed in and that their spatial distribution can change greatly when these reefs disappear. But to our knowledge, the study of Petersen and Exo (1999) in the German part of the Wadden Sea is, so far, the only extensive study investigating the role of large L. conchilega dominated tidal flats for waders and gulls. In comparison to the surrounding area, they found higher densities of four bird species feeding in these flats, though the relative biomass consumption on these flats was similar to other regions of the Wadden Sea. Furthermore, the study revealed that gulls tend to feed on L. conchilega specimens, while waders rather select the accompanying benthic macrofauna.

The area surveyed by Petersen and Exo (1999) was special because of the spatial dominance of $L$. conchilega sand flats ( $60 \%$ of the 6680 ha of the study site), and because the remaining area was covered by two other habitat-creating species: Arenicola marina (20\%) and Mytilus edulis (5 to 10\%). Despite of the dominance of L. conchilega, the tubeworm aggregates did not generate the specific sedimentological structures, typically mounds and depressions, previously described for other $L$. conchilega reefs (e.g. Carey 1987).

The aim of this current study was to quantify the role of $L$. conchilega reefs as potential "oases" for feeding waders; do the reefs constitute a localized and discrete habitat for birds among large and 
homogeneous tidal flats. Therefore, one of the largest intertidal L. conchilega reefs in Europe, located in the Bay of the Mont Saint-Michel (BMSM) (France), was selected. For the first time, a combination of macrobenthos data, bird counts and bird diet information was used to stress the importance of a Lanice conchilega reef. Following hypotheses have been tested: i) the benthic macrofaunal composition of the reef clearly differs from the macrofaunal composition of the whole bay; ii) the abundance and composition of waders on the reef is significantly different from the wader abundances and composition at the scale of the whole BMSM. Additionally, the diet of waders feeding on the reef was determined by means of a faecal analysis.

\section{Material and Methods}

Study area

The Lanice conchilega reef is located in the central region of the BMSM $\left(48^{\circ} 40^{\prime} 45^{\prime \prime} \mathrm{N}-01^{\circ} 41^{\prime} 25^{\prime \prime} \mathrm{W}\right.$, south-eastern part of the Normand-Breton Gulf, France) (Figure 1) and in the lower section of the tidal flats. In 2008, the reef covered 105 ha; i.e. $0.42 \%$ of the sand flats of the BMSM (Godet et al. 2011) (Figure 1). The BMSM is subjected to an extreme megatidal regime (tidal range up to $15.5 \mathrm{~m}$ during spring tides), resulting in large tidal flats - covering 25000 ha - and mainly dominated by a Macoma balthica community characterized by low macrobenthic abundances and diversity (Retière 1979; Thorin et al. 2001). The BMSM is an internationally important migration stopover and wintering site for birds (Le Drean-Quenec'hdu et al. 1995), designated as a RAMSAR site and classified as a Special Protection Area (SPA) and a Special Area of Conservation (SAC). More than 50000 waders overwinter in the BMSM; $12 \%$ of the French wintering abundances of waders (Le Drean-Quenec'hdu et al. 1998). At this site, Dunlin Calidris alpina, Red Knot Calidris canutus, Oystercatcher Haematopus ostralegus, Grey Plover Pluvialis squatarola, Black-tailed Godwit Limosa limosa, and Bar-tailed Godwit Limosa lapponica reach international abundance levels in winter (Deceuninck and Mahéo 2000). 
Macrobenthos sampling and treatment at the scale of the L. conchilega reef

Benthic macrofauna was sampled from the $10^{\text {th }}$ to the $12^{\text {th }}$ of January 2009 within 1 ha squares of a regular grid (consisting of 150 squares). The L. conchilega density within each square was estimated by counting aboveground tubes on pictures of 3 randomly selected $1 / 4 \mathrm{~m}^{2}$ quadrats. Samples were only taken in one out of every two squares of each row of the grid, though every square with $L$. conchilega densities $\geq 200$ ind. $\mathrm{m}^{-2}$ was sampled as well (i.e. 80 sampled squares in total) (Figure 2). The number of tubes is highly correlated with the number of individuals in the sediment (e.g. Van Hoey et al. 2006). At every selected square, one macrofaunal core was collected $\left(1 / 40 \mathrm{~m}^{2}, 30 \mathrm{~cm}\right.$ deep). Benthic samples were sieved in the field through a $1 \mathrm{~mm}$ circular mesh size and the retained biological material was immediately preserved in a $4.5 \%$ buffered formalin solution. In the laboratory, samples were sorted and macrobenthos was identified to the lowest possible taxonomic level. Total biomass was estimated by determining the dry mass of all individuals per species $\left(60^{\circ} \mathrm{C}\right.$ for $\left.48 \mathrm{~h}\right)$. The ash-free dry mass (AFDM) was calculated as the difference between the dry mass and the ash mass $\left(500{ }^{\circ} \mathrm{C}\right.$ for $3 \mathrm{~h})$.

Wader counts at the scale of the BMSM

To assess the total number of waders in the whole BMSM, all waders of the site were monitored 5 times (January '09, March '09, May '09, September '09 and January '10) by 10 to 30 people. A standardized protocol to monitor water birds of the BMSM, developed by two ornithological associations, Bretagne-Vivante/SEPNB and GONm, was followed (Beaufils et al. 2009). Waders were counted in their high-tide roosts by people equipped with telescopes and binoculars. Because of the extent of the BMSM, it was divided in sectors assigned to one or two observers. To avoid double counts, surveys in the different sectors were performed on the same day and during the same time interval (20 to $30 \mathrm{~min}$ ). Additionally, any bird group seen flying from one sector to another was systematically reported with the exact time and flight direction. 
112 On the reef, birds were surveyed 21 times from February 2009 to January 2010 (at least once each month, except for November and December), but only while spring tide fully exposed the reef (i.e. corresponding to a low tide level of less than $2.5 \mathrm{~m}$ above extreme low water spring tide). Birds were counted by two persons equipped with a pair of binoculars and a telescope (magnification respectively 10X and 20-60X). All individuals were counted (in case of a few tens of individuals) or estimated in tens of individuals (if several hundreds or thousands of individuals were present). The observation point, located on a sandbank just outside the study area, ensured visibility of the entire site as well as a minimal bird disturbance.

In 2010, faeces of five wader species were collected within the reef: Oystercatcher H. ostralegus, Dunlin C. alpina, Curlew Numenius arquata, Grey Plover P. squatarola and Bar-tailed Godwit L. lapponica. We selected these species because they: i) are abundant in the reef; ii) feed regularly on the reef; iii) are species for which faeces are easy to collect because they feed in dense and virtually monospecific groups. Faeces of Curlew and Dunlin were collected on the $27^{\text {th }}$ of April 2010, while faeces of Oystercatcher, Bar-tailed Godwit and Grey Plover were collected on the $13^{\text {th }}$ of August 2010, the $9^{\text {th }}$ of September 2010 and the $7^{\text {th }}$ of October 2010 respectively.

Prior to collection, a large monospecific flock of birds feeding on the reef was observed in order to be confident that a dropping came from the target species. After 20 to $30 \mathrm{~min}$ (in order to be sure that the collected faeces resulted from a feeding activity on the reef), the entire droppings were scraped off the surface and preserved in $70 \%$ ethanol. In the laboratory, the ethanol was removed by pouring the dropping onto a $20-\mu \mathrm{m}$ sieve. For analysis, the sample was transferred to a $100-\mathrm{ml}$ jar, containing a mix of $80 \%$ distilled water and $20 \%$ hydrogen peroxide $\left(\mathrm{H}_{2} \mathrm{O}_{2}\right)$, for a period of at least $24 \mathrm{~h}$. The samples were shaken regularly and, after sedimentation, the supernatant was poured through a $20-\mu \mathrm{m}$ sieve. The supernatant remaining on the sieve was transferred to a $25-\mathrm{cm}^{3}$ petri dish in order to observe and identify lighter animal parts (e.g. polychaete chaetae) with an inverted microscope. A 
stereo-microscope was used to screen the entire settled sand fraction for hard remnants of bivalves, polychaete jaws, etc. Prior to investigation, we selected for each of the five bird species 15 faecal samples (except for Curlew: 11 samples).

Although all different items in a faecal sample were quantified, identification to genus or species level was not always possible. Therefore, each unique unidentified animal part was assigned to a morphotype, leading up to the creation of a catalogue consisting of pictures. Finally, for several analyses morphotypes were pooled into taxonomic groups, as mentioned hereafter.

Data and statistical analysis

\section{Macrobenthic density, richness, diversity and production in the reef}

Macrobenthic densities (D), species richness (S) and species diversity (H', Shannon Index, Shannon 1948) were calculated. Abundances of macrobenthos in the L. conchilega reef were evaluated by summing the numbers of individuals from the different squares. Subsequently, relative abundances were calculated. The annual macrobenthic production in the reef was estimated using an empirical model based on biomass and abundance data (Brey 1999, 2001). The model takes additional data on benthic taxa and environmental variables such as bathymetry and temperature in consideration. Prior to production estimation, benthic biomass in $\mathrm{g}$ of AFDM was converted to $\mathrm{kJ}$ via conversion factors for aquatic organisms (Brey 2001; Brey et al. 2010).

\section{Abundances and community composition of waders on the reef versus the entire BMSM}

The community composition of waders was analysed with the PRIMER v6 statistical package (Clarke and Warwick 1994). Analysis of similarity (one-way ANOSIM) was used to describe (dis-)similarities in wader communities between the entire bay and the L. conchilega reef. Data were standardized (in order to eliminate the abundance effect) and square root transformed before conducting the analysis. To test whether waders significantly selected the reef at low tide, we compared the abundances of waders present on the reef with predicted wader abundances present on the reef assuming a homogeneous distribution of birds across the entire BMSM during low tide. Because the ratio of the area covered by the reef to the area of the tidal flats is 1:238 (105 ha reef among 25000 ha of tidal 
flats), counting $\mathrm{n}$ individuals of a species at high tide in the whole BMSM results in a predicted abundance of $n / 238$ individuals of this species on the reef. Only counts which were performed at similar time periods over the entire BMSM and the reef were selected for the analysis; i.e. four observation dates (March '09, May '09, September '09, and January '10). The number of days between a count across the BMSM and on the reef varied between 0 and 12 days. $G$-tests for goodness-of-fit were conducted in order to compare predicted and actual abundances of waders on the reef, assuming no selective use of the reef habitat. A significant total $G$-value means that the data do not fit the expected ratio.

\section{Analysing bird faeces data}

First, differences in the frequency of occurrence of benthic taxa among wader species were investigated. Therefore, bird faeces data were transformed into presence/absence data, followed by lumping morphotypes into taxonomic groups. Due to diagnostic features of some morphotypes they could be linked to a certain species. Nonetheless, in most of the cases it was not possible to assign a morphotype to a species but only to an order, class, or even phylum. For every wader species, the frequency of occurrence for each taxon $i(\mathrm{FOi} \%)$ was calculated: $\mathrm{FOi} \%=$ (the number of faecal samples of the wader species $s$ where taxon $i$ is present / the total number of faecal samples of the wader species $s) * 100$. Second, to determine which taxa are preferentially found in faecal samples of particular wader species, the proportion of different taxonomic groups (Ni\%) per faecal sample was calculated: $\mathrm{Ni} \%=($ Number of items in taxonomic group $i /$ total number of items in the faecal sample $)$

* 100. To test whether relative abundances of higher taxonomic groups and the most abundant lower taxonomic groups differed significantly among bird species, a generalized linear model (GLM) was used in the SAS 9.2 software package (Glimmix procedure). Because the response variables are percentage data, the residual error structure was tested against a binomial distribution. When overdispersion became apparent in the model output, the model was rerun, taking the overdispersion into account by adding an overdispersion component (random residual) to the variance function. Accordingly, underestimation of the standard errors was avoided. Because the predictor and the mean response are not linearly related to each other, the relationship was specified by a log link function. 
Macrobenthic density, richness, diversity, biomass and production in the Lanice conchilega reef

192

193

194

195

196

197

In 2009, 13806 macroinvertebrates belonging to 61 different taxa were sampled on the reef. Excluding L. conchilega itself, the macrobenthic abundance was dominated by the bivalves Macoma balthica and Cerastoderma edule and the polychaete Nephtys hombergii. Taking into account $L$. conchilega, the mean density of macrobenthic species was $6903 \pm 5339$ ind. $\mathrm{m}^{-2}, N=80$; mean species richness was $11.8 \pm 4.7$ species per square and mean species diversity ( $\left.\mathrm{H}^{\prime}\right)$ was $2.1 \pm 0.5$. At the phylum level, the benthic community within the reef was dominated by annelids (59\%), followed by molluscs (38\%) and arthropods (1.8\%). More than $99.9 \%$ of the annelids in the reef belonged to the class Polychaeta. Moreover, this taxon was dominated by L. conchilega (69\%). The average $L$. conchilega density was $200 \pm 351$ ind. $\mathrm{m}^{-2}, N=150$, and a maximum density of 1985 ind. $\mathrm{m}^{-2}$ was reached. Within the phylum of Mollusca, the most abundant species were M. balthica (55\%) and $C$. edule (44\%). Crustaceans were the most abundant taxon within the phylum of the arthropods (99.6\%). The order of the amphipods (71\%) dominated the crustaceans within the reef. Cumaceans, isopods and decapods (crabs) constituted respectively $14.7 \%, 7.8 \%$, and $6.5 \%$ of total abundances. The mean benthic biomass in the reef was $49.7 \pm 50.4 \mathrm{~g}$ of AFDM.m ${ }^{-2}$. The annual macrobenthic production in the reef (95\% confidence interval) was estimated at $1552.9(1368.5-1762.3) \mathrm{kJ} \cdot \mathrm{m}^{-2} . \mathrm{year}^{-1}$ or $70.6 \mathrm{~g}$ AFDM.m ${ }^{-2} \cdot$ year $^{-1}(60.2-80.1)$.

Wader density and community composition in the BMSM and on the reef

Across the entire BMSM, 22 wader species were counted, representing a mean density of $1.03 \pm 0.58$ birds ha ${ }^{-1}, N=5$. The five most abundant species were: Dunlin (42\%), Red Knot (18\%), Oystercatcher (13\%), Grey Plover (9\%) and Curlew (7\%). On the reef, 15 wader species were counted, representing a mean density of $51.38 \pm 19.11$ birds $^{-1} a^{-1}, N=5$. Dunlin (39\%) was the most abundant species on the reef followed by Red Knot (20\%), Grey Plover (14\%), Oystercatcher (13\%), Bar-tailed Godwit (8\%) and Curlew (5\%). 
The one-way global ANOSIM test failed to detect a significant difference in the wader community in the two habitats $(\mathrm{p}>0.05 ; \mathrm{R}=0.108)$. Unlike bird composition, bird counts revealed that all wader species together exhibited a high proportion of individuals in the reef in relation to the whole BMSM (Table 1). The frequency of waders in the reef was on average 46.6 times higher than expected assuming a random distribution of waders over the entire BMSM. The same was observed for the five wader species selected for the faecal analysis. Focussing on each of the 5 wader species separately revealed frequencies ranging from 31.1 times (Curlew) up to 112.3 times (Bar-tailed Godwit) higher than expected. Consequently, the observed numbers of these 5 species in the reef were significantly higher than their predicted numbers (assuming that the total number of waders counted at high tide have a homogeneous distribution in the BMSM at low tide) (for each species, G-test, $\mathrm{p}<0.001$ ).

\section{Diet of waders feeding on the reef}

In general, the frequency of occurrence (FO\%) of higher taxonomic groups in the faeces did not differ much among different bird species (Table 2). Crustaceans were present in all faecal samples of all birds except for Bar-tailed Godwit $(\mathrm{FO} \%=93.3 \%)$. Both polychaetes and bivalves were present in all bird species but polychaetes in a much higher percentage of the faeces (ranging from $72.7 \%$ in Curlew to $93.3 \%$ in Dunlin) than bivalves (ranging from $13.3 \%$ in Oystercatcher and Grey Plover to $45.5 \%$ in Curlew). Lanice conchilega was eaten by all birds though it never exceeded a FO\% of $63.6 \%$. Other polychaetes were scarce. Crabs, amphipods and ostracods - the most abundant crustacean groups in the faeces - were encountered in all bird species and reached the highest FO\% in Curlew (respectively $81.8 \%, 45.5 \%$ and $90.9 \%$ ). The three most frequently occurring bivalve species among all bird species were Abra alba, C. edule and M. balthica, although they never exceeded a FO\% of $6.7 \%, 36.4 \%$, and $20 \%$ respectively.

Based on the relative abundances of taxonomic groups in each of the 5 bird species a diet composition can be displayed for the 5 bird species examined (Table 3). Relative abundances of all higher taxonomic groups differed significantly $(\mathrm{p}<0.05)$ among the 5 wader species $(\mathrm{GLM}, \mathrm{p}<0.05$, Table 4). Globally, polychaetes differed significantly among species of birds, though no significant pairwise 
differences were detected. Crustaceans were more frequently eaten by Curlew than by Oystercatcher or Bar-tailed Godwit, while bivalves were eaten more frequently by Dunlin than Curlew. Significant differences in the relative abundances of $L$. conchilega (GLM, p < 0.0001) and 'Other polychaetes' (GLM, $\mathrm{p}<0.0001$ ) were detected among bird species (Table 5). According to pairwise tests, $L$. conchilega was eaten more frequently by Oystercatcher than by Dunlin and Curlew. Additionally, Bar-tailed Godwit ate L. conchilega more frequently than Dunlin, but less than Curlew. Within the group of crustaceans, 'Crabs' differed significantly among bird species (GLM, p = 0.005), although no significant pairwise differences were detected. Lastly, no bivalve species showed a significant difference among waders (GLM, $\mathrm{p}>0.05)$.

\section{Discussion}

Our study showed that the Lanice conchilega reef of the BMSM is remarkable because of the wader density which easily exceeds the expected frequency. In the entire BMSM a total of 22 wader species was observed and counted during the study period, while only 15 species were observed in the $L$. conchilega reef. Since the entire BMSM is almost 240 times bigger than the reef area, the observed difference in species richness is not surprising keeping in mind the species-area relationship (Connor and McCoy 1979). Consequently, species that were rarely counted at the scale of the entire BMSM are not likely to be observed at the scale of the reef. Despite this difference, both areas were mainly dominated by the same species: Dunlin, Red Knot, Grey Plover, Oystercatcher and Curlew. Eybert et al. (2003) already demonstrated that $96 \%$ of the wintering shorebird community in the entire BMSM was represented by 7 species: Dunlin, Oystercatcher, Red Knot, Curlew, Grey Plover, Bar-tailed Godwit and Black-tailed Godwit. Overall, the composition of waders can be considered the same in the entire BMSM and the reef.

However, when abundances are included, the composition of waders clearly differed between the two study sites. The observed frequency of total waders on the Lanice-reef was on average 5799 birds, which is approximately 46.6 times higher than expected assuming a uniform distribution of the birds in the BMSM. Petersen and Exo (1999) observed higher than expected bird abundances in $L$. 
conchilega dominated tidal flats of the Wadden Sea, although densities were only 6 times higher than expected. Similar counting surveys in the Chausey archipelago (France) and preliminary counts in the BMSM already showed the attractiveness of the L. conchilega reefs for birds and consequently their potentially important role in the conservation of the avifauna (Godet et al. 2008). The results of the current study prove that within a site of international importance for birds, several wader species are able to select preferentially habitats generated by L. conchilega.

In general, the attractiveness of $L$. conchilega reefs can be attributed to the good food supply, i.e. the high diversity, abundance and biomass of associated macrobenthic invertebrates, as proven by several authors in different study areas (e.g. Zühlke et al. 1998; Zühlke 2001; Callaway 2006; Rabaut et al. 2007; Van Hoey et al. 2008). The situation in the L. conchilega reef of the BMSM seems to be alike. In our study, the macrofaunal density is 4.4 times higher than in a study of Trigui (2009), which investigated the general characteristics of the benthic macrofauna of the entire intertidal zone of the BMSM in 2003. Trigui's survey is, with 176 sampled stations, the most extensive benthic survey ever done in the BMSM. Comparison with current research reflects well the fact that the reef does accommodate a more abundant fauna (6 $903 \pm 5339$ ind. $\left.\mathrm{m}^{-2}\right)$ than the average macrobenthic assemblage in the entire BMSM (1 $568 \pm 299$ ind. $\left.\mathrm{m}^{-2}\right)$. As part of a study of Leloup et al. (2008), biomasses of different trophic groups which make up the BMSM were modelled. The biomass of carnivorous and necrophagous macrobenthic fauna in combination with intertidal filter feeders was transformed according to weight-to-weight conversion factors proposed by Ricciardi and Bourget (1998). Comparing the resulting biomass (2.88 g AFDM. $\mathrm{m}^{-2}$ ) to the reef biomass (49.69 g AFDM. $\mathrm{m}^{-2}$ ) revealed a reef biomass which is more than 17 times higher. Therefore, the reef area can be considered a high productivity area in the bay. Nevertheless, the importance of the whole BMSM for the productivity and functioning of the reef cannot be neglected.

Faecal analysis conducted in this study revealed information on the diet composition of waders in the reef. Polychaetes were represented in all bird species and they occurred in a high percentage of the faecal samples, which can probably be attributed to the dominance of polychaetes in the reef benthos. Lanice conchilega was the most abundant species and polychaete in the reef, which was partially 
reflected in the faecal samples since L. conchilega was the only identifiable polychaete species present in all bird species. Nevertheless, based on the relative abundances on the reef it could be expected that L. conchilega counted as a larger part of a bird's diet. The fact that the tube-building polychaete is large (up to 30cm; Hartmann-Schröder 1996), sturdy and buried quite deeply in the sediment (Jones and Jago 1993) can lead to a lower accessibility and possibly explains the lower than expected portion of $L$. conchilega in the diet of waders. Additionally, the fact that the energy content of polychaetes in temperate waters is high (Dauvin and Joncourt 1989), in combination with the high biomass of $L$. conchilega in the reef, might lead to the great contribution of one individual to the nutritional demands of birds. The bivalves Macoma balthica and Cerastoderma edule were, next to L. conchilega, the most abundant macrobenthic species in the reef. However, the general occurrence and portion of these two species in the diet of the investigated bird species was low. Even in Oystercatchers, which are specialized bivalve feeders (e.g. Hulscher 1982), bivalves were underrepresented. A feeding strategy avoiding the uptake of bivalve shell pieces, as described by Hulscher (1982), and hence the low detection success of shell remains in the faeces of Oystercatchers, is the most plausible explanation. Crustaceans, and in particular crabs and ostracods, were the most frequently occurring and abundant taxonomic group in the faeces of all bird species. However, relative abundances of crustaceans in the reef benthos were very low ( $1.77 \%$ of the total abundance), particularly for crabs. The observed ubiquity of crabs (and crustaceans in general) in the faecal samples implies a selective feeding behaviour of waders for this benthic group, which may be due to the fact that the stimuli associated with crustaceans, can have properties which make them particularly perceptible to the avian eye (Goss-Custard 1977).

Based on relative abundances of taxonomic groups, bird species that largely dominate the wader community on the reef exhibited significant differences in their dietary composition. Differences in polychaetes, and especially L. conchilega, contributed highly to differences in the wader diets. Differences in diets due to bivalves were rather low and in all probability largely overshadowed by an inability to trace back bivalve shells in faeces. For crustaceans, differences in the relative abundance between waders were the result of significant differences in crabs, though no significant pairwise tests 
were noted. Nevertheless, it can be visually seen that crabs reached much higher abundances in the

322 faeces of Curlew compared to other waders (Table 3), which is in accordance with studies revealing

323 that crabs are a major food source of Curlew (e.g. Goss-Custard and Jones 1976).

324 Considering the frequency of occurrence of taxonomic groups in the diet, waders foraging within the 325 reef can be seen as opportunistic feeders, while focusing on the relative abundance gives the impression of a more selective feeding strategy. Based on current wader diet analysis, the actual strategy in the reef probably lies somewhere in between these two extremes. In general, waders feeding on the reef tend to feed on the associated fauna, and especially crustaceans, rather than specifically on $L$. conchilega. This result confirms the investigations of Petersen and Exo (1999), providing evidence that $L$. conchilega, within $L$. conchilega dominated tidal flats, was a less important food source for birds (mainly waders) than the accompanying macrobenthos. However, L. conchilega was of overriding importance for a few species, especially for gulls (Petersen and Exo 1999).

As experienced in this current study, investigating bird faeces can give us better insights into the diet of waders feeding in the reef. However, faecal analysis is hampered by a high proportion of unidentified prey items and is unlikely to reveal all prey taken by the predator (Barrett et al. 2007). Despite some shortcomings, faecal analysis is a valuable and easily applicable technique for which samples can be obtained all-year round without causing harm to the birds. Moreover, this approach can reveal the presence of prey species which could not be noticed by means of visual observations. Nevertheless, to get a more complete view on a wader's diet, the use of complementary approaches (e.g. visual observations) is recommended (Scheiffarth 2001). In this study morphotypes were counted, which cannot be compared with specimens. Since morphotypes are mostly parts of animals and can belong to one or several specimens of the same species or taxonomic group, caution regarding the interpretation of the results is recommended. Faecal samples of the wader species were collected on different dates ranging from the end of April 2010 until the beginning of October 2010. It is known that the diet composition of waders, as well as the nutritive value of some macrobenthic organisms, can change seasonally (e.g. Scheiffarth 2001; Braeckman et al. 2012). Furthermore, sexual differences

347 in the diet composition have been demonstrated for several birds (e.g. Bar-tailed Godwit; Scheiffarth 

2001). As neither sexual nor seasonal variations in the diet composition of waders were taken into account in our study, comparing wader diets is restricted. Additionally, future studies should try to compare diet composition of waders both inside and outside the L. conchilega reef.

Evaluating the importance of Lanice conchilega reefs as trophic resources for waders is not merely fundamental to gain knowledge on the feeding ecology, but is also essential for predicting the effects of a possible loss of the reef habitat in the future. Overall, the L. conchilega reef of the BMSM can be considered an oasis within the tidal flats composed of a similar composition of waders but with much higher bird densities compared to the non-reef areas of the BMSM. This result clearly demonstrates that birds are attracted by the reef. According to faecal analyses, waders in the L. conchilega reef tend to feed on the associated fauna, and especially crustaceans, rather than specifically on L. conchilega itself. Within the BMSM, which is characterized by low species diversity and low macrofaunal abundances, the L. conchilega reef constitutes a rich feeding area. For future studies, the use of complementary techniques to study a wader's diet is recommended, as well as the inclusion of information on the alimentary regime of waders in the BMSM.

\section{Acknowledgements}

We thank Matthieu Beaufils (Bretagne-Vivante/SEPNB, La société pour l'Etude et la Protection de la Nature en Bretagne, and GONm, Groupe Ornithologique Normand), Sébastien Provost (GONm) and Régis Morel (Bretagne-Vivante/SEPNB) for coordinating and providing the bird counts at the scale of the BMSM for 2009. Both Bretagne-Vivante/SEPNB and the GONm are acknowledged for funding the counts at the scale of the BMSM. Thanks to Thomas Brey for providing and helping with the empirical model to estimate benthic production and to Andrea Moore for help with the faecal analysis. We also thank the anonymous reviewers who improved earlier versions of the manuscript. The first author acknowledges a $\mathrm{PhD}$ scholarship provided by the Special Research Fund (BOF), Ghent University, Belgium. The second author acknowledges the 'Centre National de la Recherche Scientifique' for his Post-Doc Grant. 
Barrett RT, Camphuysen K, Anker-Nilssen T, Chardine JW, Furness RW, Garthe S, Hüppop O, Leopold MF, Montevecchi WA, Veit RR (2007) Diet studies of seabirds: a review and recommendations. Ices J Mar Sci 64 (9):1675-1691

Beaufils M, Morel R, Provost S (2009) Suivi 2009 de la fréquentation de la Baie du Mont SaintMichel par les oiseaux d'eau. Rapport SEPNB-GONm

Braeckman U, Provoost P, Sabbe K, Soetaert K, Middelburg JJ, Vincx M, Vanaverbeke J (2012) Temporal dynamics in the diet of two marine polychaetes as inferred from fatty acid biomarkers. J Sea Res 68 (0):6-19. doi:10.1016/j.seares.2011.11.003

Brey $\mathrm{T}$ (1999) A collection of empirical relations for use in ecological modelling. NAGA The ICLARM Quarterly 22 (3):24-28

Brey T (2001) Population dynamics in benthic invertebrates. A virtual handbook. http://www.thomasbrey.de/science/virtualhandbook. Accesses 1st February 2012.

Brey T, Muller-Wiegmann C, Zittier ZMC, Hagen W (2010) Body composition in aquatic organisms A global data bank of relationships between mass, elemental composition and energy content. J Sea Res 64 (3):334-340. doi:10.1016/j.seares.2010.05.002

Callaway R (2006) Tube worms promote community change. Mar Ecol-Prog Ser 308:49-60. doi:10.3354/meps308049

Callaway R, Desroy N, Dubois SF, Fournier J, Frost M, Godet L, Hendrick VJ, Rabaut M (2010) Ephemeral Bio-engineers or Reef-building Polychaetes: How Stable are Aggregations of the Tube Worm Lanice conchilega (Pallas, 1766)? Integrative and Comparative Biology 50 (2):237-250. doi:10.1093/icb/icq060

Carey DA (1987) Sedimentological effects and paleoecological implications of the tube-building polychaete Lanice conchilega Pallas. Sedimentology 34 (1):49-66. doi:10.1111/j.13653091.1987.tb00559.x

Clarke KR, Warwick RM (1994) Change in marine communities: an approach to statistical analysis and interpretation. Primer-E Plymouth Marine Laboratory, UK

Connor EF, McCoy ED (1979) The Statistics and Biology of the Species-Area Relationship. Am Nat $113(6): 791-833$

Dauvin JC, Joncourt M (1989) Energy values of marine benthic invertebrates from the western english channel. Journal of the Marine Biological Association of the United Kingdom 69 (3):589-595

Deceuninck B, Mahéo R (2000) Synthèse des dénombrements et analyse des tendances des limicoles hivernant en France 1978-1999. Rapport DNP:82

Eybert M-C, Geslin T, Questiau S, Feunteun E (2003) Shorebird community variations indicative of a general perturbation in the Mont-Saint-Michel (France). CR Biologies 326:140-147

Feral P (1989) Influence des populations de Lanice conchilega (Pallas)(Annelida, Polychaeta) sur la sedimentation sableuse intertidale de deux plages bas-normandes (France). Bull Soc Geol Fr 8:1193-1200 
Godet L, Toupoint N, Olivier F, Fournier J, Retière C (2008) Considering the functional value of common marine species as a conservation stake: The case of sandmason worm Lanice conchilega (Pallas 1766) (Annelida, Polychaeta) beds. Ambio 37 (5):347-355. doi:10.1579/07-a-317.1

Godet L, Toupoint N, Fournier J, Le Mao P, Retiere C, Olivier F (2009) Clam farmers and Oystercatchers: Effects of the degradation of Lanice conchilega beds by shellfish farming on the spatial distribution of shorebirds. Mar Pollut Bull 58 (4):589-595. doi:10.1016/j.marpolbul.2008.11.001

Godet L, Fournier J, Jaffre M, Desroy N (2011) Influence of stability and fragmentation of a wormreef on benthic macrofauna. Est Coast Shelf Sci 92 (3):472-479. doi:10.1016/j.ecss.2011.02.003

Goss-Custard JD (1977) The energetics of prey selection by redshank, Tringa totanus (L.), in relation to prey density. J Anim Ecol 46 (1):1-19

Goss-Custard JD, Jones RE (1976) The diets of redshank and curlew. Bird Study 23:233-270

Hartmann-Schröder G (1996) Annelida, Borstenwürmer, Polychaeta. In: The fauna of Germany and adjacent seas with their characteristics and ecology, second revised ed., vol. 58. Gustav Fisher, Jena, Germany, 648 p.

Hulscher JB (1982) The oystercatcher Haematopus ostralegus as a predator of the bivalve Macoma balthica in the dutch Wadden Sea. Ardea 70 (2):89-152

Jones SE, Jago CF (1993) In situ assessment of modification of sediment properties by burrowing invertebrates. Mar Biol 115:133-142

Le Drean-Quenec'hdu S, Mahéo R, Boret P (1995) The Mont Saint-Michel bay: a site of international importance for wintering Palearctic waders. Wader Study Group Bull 77:50-54

Le Drean-Quenec'hdu S, Mahéo R, Boret P (1998) Les limicoles. Penn ar bed 169: La Baie du Mont Saint-Michel:1-10

Leloup FA, Desroy N, Le Mao P, Pauly D, Le Pape O (2008) Interactions between a natural food web, shellfish farming and exotic species: The case of the Bay of Mont Saint Michel (France). Est Coast Shelf Sci 76 (1):111-120. doi:10.1016/j.ecss.2007.06.011

Petersen B, Exo KM (1999) Predation of waders and gulls on Lanice conchilega tidal flats in the Wadden Sea. Mar Ecol Prog Ser 178:229-240. doi:10.3354/meps178229

Rabaut M, Guilini K, Van Hoey G, Vincx M, Degraer S (2007) A bio-engineered soft-bottom environment: The impact of Lanice conchilega on the benthic species-specific densities and community structure. Est Coast Shelf Sci 75 (4):525-536. doi:10.1016/j.ecss.2007.05.041

Rabaut M, Vincx M, Degraer S (2009) Do Lanice conchilega (sandmason) aggregations classify as reefs? Quantifying habitat modifying effects. Helgoland Mar Res 63 (1):37-46. doi:10.1007/s10152-008-0137-4

Rabaut M, Van de Moortel L, Vincx M, Degraer S (2010) Biogenic reefs as structuring factor in Pleuronectes platessa (Plaice) nursery. J Sea Res 64 (1-2):102-106. doi:10.1016/j.seares.2009.10.009

Retière C (1979) Contribution à la connaissance des peuplements benthiques du Golfe NormanoBreton. Dissertation, Université de Rennes 
Ricciardi A, Bourget E (1998) Weight-to-weight conversion factors for marine benthic macroinvertebrates. Mar Ecol Prog Ser 163:245-251. doi:10.3354/meps163245

Rijnsdorp AD, Vingerhoed B (2001) Feeding of plaice Pleuronectes platessa L. and sole Solea solea (L.) in relation to the effects of bottom trawling. J Sea Res 45 (3-4):219-229. doi:10.1016/s1385-1101(01)00047-8

Scheiffarth G (2001) The diet of Bar-tailed Godwits Limosa lapponica in the Wadden Sea: Combining visual observations and faeces analyses. Ardea 89 (3):481-494

Shannon CE (1948) A mathematical theory of communication. Bell System Technical Journal 27:379423

Thorin S, Radureau A, Feunteun E, Lefeuvre JC (2001) Preliminary results on a high east-west gradient in the macrozoobenthic community structure of the macrotidal Mont Saint-Michel bay. Cont Shelf Res 21 (18-19):2167-2183. doi:10.1016/s0278-4343(01)00050-4

Trigui RJ (2009) Influence des facteurs environnementaux et anthropiques sur la structure et la fonctionnement des peuplements benthiques du Golfe Normano-Breton. Dissertation, Muséum National d'Histoire Naturelle, France

Van Hoey G, Vincx M, Degraer S (2006) Some recommendations for an accurate estimation of Lanice conchilega density based on tube counts. Helgoland Mar Res 60 (4):317-321. doi:10.1007/s10152-006-0041-8

Van Hoey G, Guilini K, Rabaut M, Vincx M, Degraer S (2008) Ecological implications of the presence of the tube-building polychaete Lanice conchilega on soft-bottom benthic ecosystems. Mar Biol 154 (6):1009-1019. doi:10.1007/s00227-008-0992-1

Yates MG, Goss-Custard JD, McGrorty S, Lakhani KH, Durell S, Clarke RT, Rispin WE, Moy I, Yates T, Plant RA, Frost AJ (1993) Sediment characteristics, invertebrate densities and shorebird densities on the inner banks of the Wash. J Appl Ecol 30 (4):599-614. doi: $10.2307 / 2404240$

Zühlke R (2001) Polychaete tubes create ephemeral community patterns: Lanice conchilega (Pallas, 1766) associations studied over six years. J Sea Res 46 (3-4):261-272. doi:10.1016/s13851101(01)00091-0

Zühlke R, Blome D, Van Bernem KH, Dittmann S (1998) Effects of the tube-building polychaete Lanice conchilega (Pallas) on benthic macrofauna and nematodes in an intertidal sandflat. Senckenb Marit 29:131-138 
484 Fig. 1 Location of the Bay of the Mont Saint-Michel (BMSM, France) and the Lanice conchilega reef 485 within the bay

486 Fig. 2 Macrobenthic sampling design and mean Lanice conchilega densities on the L. conchilega reef 487 in the Bay of the Mont Saint-Michel (BMSM) from 2005 to 2008. Macrobenthic samples were taken 488 at alternating squares of each row of the grid (consisting of 150 squares). In addition, every square 489 with a mean L. conchilega density $\geq 200$ ind. $\mathrm{m}^{-2}$ was sampled as well, resulting in 80 sampled squares 490 in total 


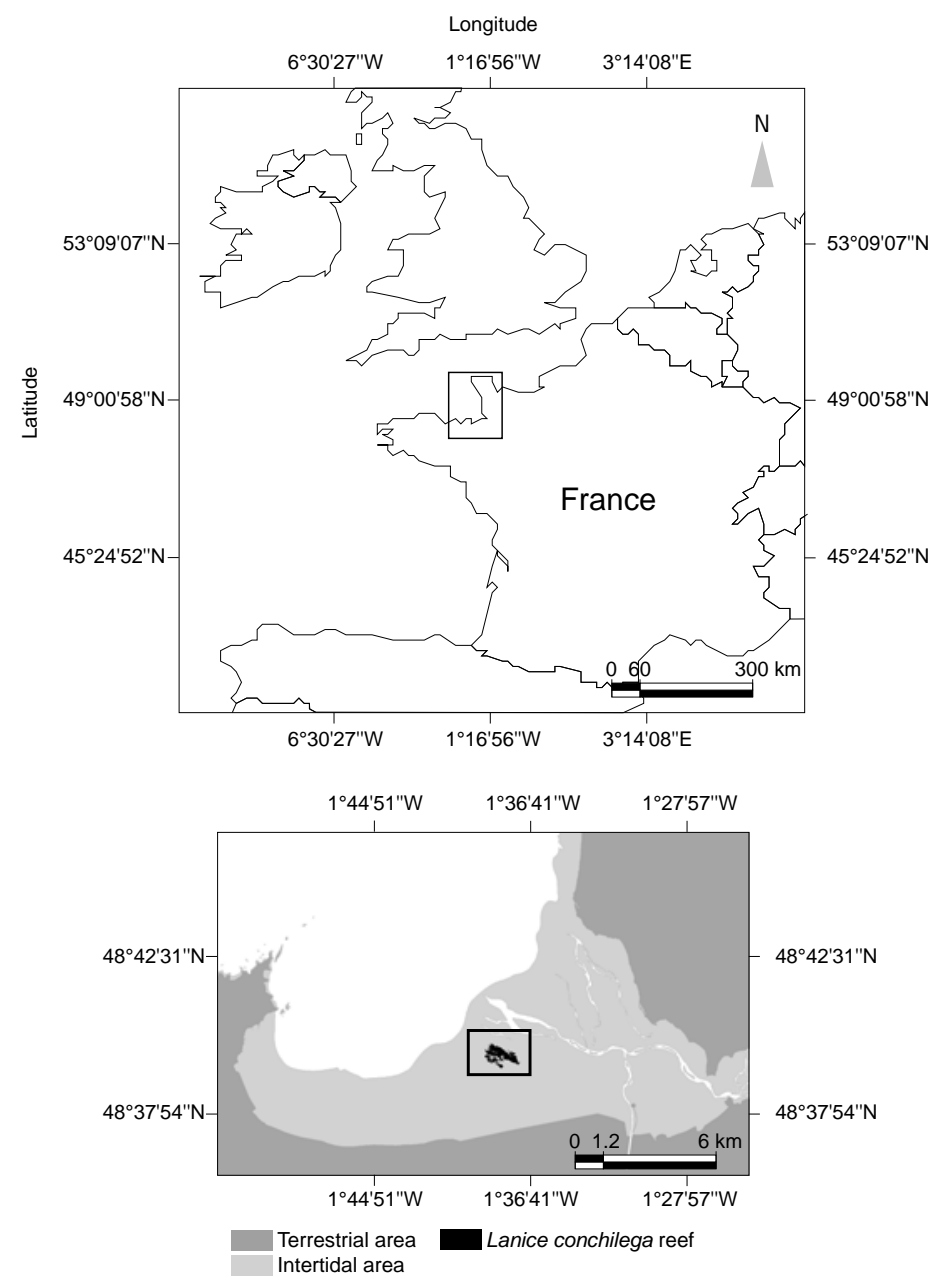




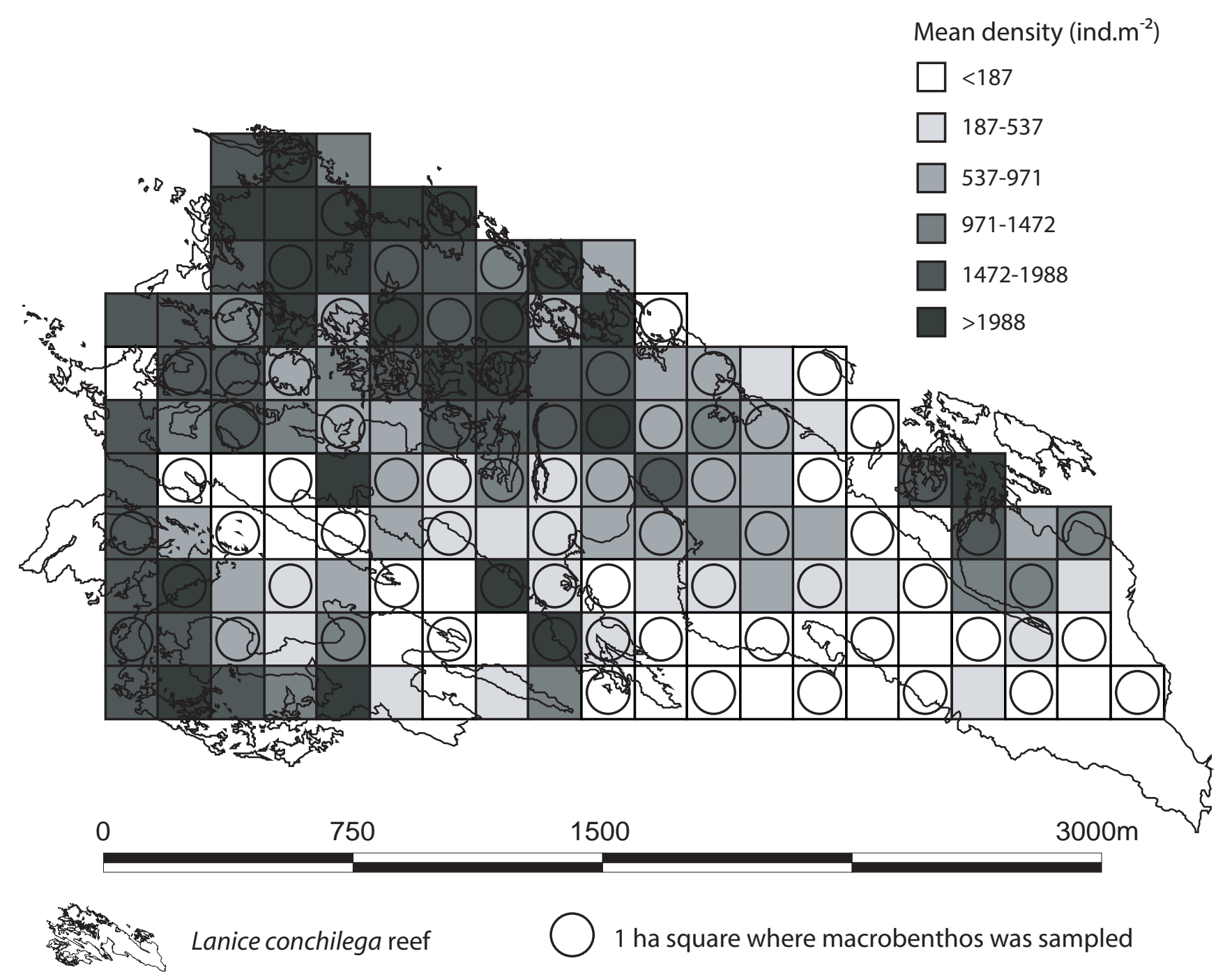


Table 1 Overview of the mean observed and mean expected bird frequencies, and the ratios of these frequencies, for the entire Bay of the Mont Saint-Michel (BMSM) and the L. conchilega reef; total Gvalues, and p-values (G-test) of different groups of birds. Observed frequencies in the BMSM and the L. conchilega reef were derived from bird counts in March '09, May '09, September '09, and January ' 10

\begin{tabular}{|c|c|c|c|c|c|c|c|c|}
\hline & \multicolumn{3}{|c|}{ BMSM } & \multicolumn{3}{|c|}{ Lanice-reef } & \multirow[b]{2}{*}{$\begin{array}{c}\text { Total } \\
G \text {-value }\end{array}$} & \multirow[b]{2}{*}{ p-value } \\
\hline & $\begin{array}{l}\text { Obs. freq. } \\
\pm \mathrm{SD}\end{array}$ & $\begin{array}{l}\text { Exp. freq. } \\
\pm \text { SD }\end{array}$ & Ratio & $\begin{array}{c}\text { Obs. freq. } \\
\pm \mathrm{SD}\end{array}$ & $\begin{array}{c}\text { Exp. freq. } \\
\pm \mathrm{SD}\end{array}$ & Ratio & & \\
\hline Total waders & $23928 \pm 15976$ & $29602 \pm 17513$ & 0.81 & $5799 \pm 1994$ & $124 \pm 74$ & 46.64 & 140976 & $<0.0001$ \\
\hline 5 Species & $17651 \pm 10761$ & $21830 \pm 12882$ & 0.81 & $4271 \pm 2444$ & $92 \pm 54$ & 46.58 & 101915 & $<0.0001$ \\
\hline Dunlin & $9853 \pm 9478$ & $12080 \pm 11337$ & 0.82 & $2278 \pm 1972$ & $51 \pm 48$ & 44.90 & 53565 & $<0.0001$ \\
\hline Oystercatcher & $3381 \pm 1963$ & $3916 \pm 2502$ & 0.86 & $551 \pm 614$ & $16 \pm 11$ & 33.52 & 12206 & $<0.0001$ \\
\hline Grey Plover & $2315 \pm 884$ & $3157 \pm 1476$ & 0.73 & $856 \pm 798$ & $13 \pm 6$ & 64.52 & 23768 & $<0.0001$ \\
\hline Curlew & $1734 \pm 1171$ & $1984 \pm 1340$ & 0.87 & $259 \pm 274$ & $8 \pm 6$ & 31.08 & 5642 & $<0.0001$ \\
\hline Bar-tailed Godwit & $369 \pm 400$ & $694 \pm 819$ & 0.53 & $327 \pm 425$ & $3 \pm 3$ & 112.34 & 10697 & $<0.0001$ \\
\hline
\end{tabular}


Table 2 Frequency of occurrence (FOi\%) of higher and the most abundant lower taxonomic groups for all five investigated waders, based on faecal analysis. $\mathrm{N}=$ the number of faecal samples investigated. $100 \%=$ present in all droppings

\begin{tabular}{lccccc}
\hline Taxon & $\begin{array}{c}\text { C. alpina } \\
\text { (Dunlin) }\end{array}$ & $\begin{array}{c}\text { H. ostralegus } \\
\text { (Oystercatcher) }\end{array}$ & $\begin{array}{c}\text { N. arquata } \\
\text { (Curlew) }\end{array}$ & $\begin{array}{c}\text { P. squatarola } \\
\text { (Grey Plover) }\end{array}$ & $\begin{array}{c}\text { L. lapponica } \\
\text { (Bar-tailed Godwit) }\end{array}$ \\
\hline Polychaeta & $\mathbf{N}=15$ & $\mathbf{N}=11$ & N $=15$ & N = \\
Lanice conchilega & 40 & $\mathbf{7 3 . 3}$ & $\mathbf{7 2 . 7}$ & $\mathbf{7 3 . 3}$ & $\mathbf{8 6 . 7}$ \\
Nereis sp. & 6.7 & 60 & 63.6 & 13.3 & 33.3 \\
Eteone longa & 0 & 0 & 9.1 & 0 & 0 \\
Other polychaetes & 93.3 & 73.3 & 9.1 & 0 & 0 \\
Crustacea & $\mathbf{1 0 0}$ & $\mathbf{1 0 0}$ & $\mathbf{1 0 0}$ & $\mathbf{1 0 0}$ & 73.3 \\
Crab sp. & 73.3 & 53.3 & 81.8 & 80 & $\mathbf{9 3 . 3}$ \\
Amphipoda sp. & 33.3 & 33.3 & 45.5 & 26.7 & 46.7 \\
Ostracoda sp. & 80 & 73.3 & 90.9 & 53.3 & 33.3 \\
Isopoda sp. & 0 & 0 & 9.1 & 0 & 40 \\
Cumacea sp. & 0 & 0 & 9.1 & 0 & 6.7 \\
Copepoda sp. & 0 & 13.3 & 0 & 33.3 & 6.7 \\
Other crustaceans & 100 & 100 & 100 & 100 & 20 \\
Bivalvia & $\mathbf{3 3 . 3}$ & $\mathbf{1 3 . 3}$ & $\mathbf{4 5 . 5}$ & $\mathbf{1 3 . 3}$ & 93.3 \\
Abra alba & 0 & 6.7 & 0 & 6.7 & $\mathbf{2 6 . 7}$ \\
Aequipecten opercularis & 0 & 0 & 9.1 & 0 & 6.7 \\
Cerastoderma edule & 0 & 0 & 36.4 & 6.7 & 0 \\
Macoma balthica & 20 & 0 & 9.1 & 0 & 0 \\
Mysella bidentata & 0 & 0 & 0 & 0 & 0 \\
Nucula sp. & 0 & 6.7 & 0 & 0 & 6.7 \\
Scrobicularia plana & 0 & 0 & 0 & 0 & 0 \\
Spisula subtruncata & 0 & 0 & 18.2 & 0 & 6.7 \\
Other bivalves & 26.7 & 0 & 18.2 & 0 & 0 \\
Other & $\mathbf{1 0 0}$ & $\mathbf{1 0 0}$ & $\mathbf{1 0 0}$ & $\mathbf{1 0 0}$ & $\mathbf{1 0 0}$ \\
\hline & & & & & \\
\hline
\end{tabular}


Table 3 Relative abundance ( \pm SD) of all higher and the most abundant lower taxonomic groups in the diet composition of all five investigated wader species, based on faecal analysis. $\mathrm{N}=$ the number of faecal samples investigated

\begin{tabular}{|c|c|c|c|c|c|c|c|c|c|c|c|}
\hline & \multirow[b]{2}{*}{ Taxon } & \multicolumn{2}{|c|}{$\begin{array}{l}\text { C. alpina } \\
\text { (Dunlin) } \\
\mathrm{N}=15\end{array}$} & \multicolumn{2}{|c|}{$\begin{array}{c}\text { H. ostralegus } \\
\text { (Oystercatcher) } \\
\mathrm{N}=15\end{array}$} & \multicolumn{2}{|c|}{$\begin{array}{c}\text { N. arquata } \\
\text { (Curlew) } \\
\mathrm{N}=11\end{array}$} & \multicolumn{2}{|c|}{$\begin{array}{c}\text { P. squatarola } \\
\text { (Grey Plover) } \\
\mathrm{N}=15\end{array}$} & \multicolumn{2}{|c|}{$\begin{array}{c}\text { L. lapponica } \\
\text { (Bar-tailed Godwit) } \\
\mathrm{N}=15\end{array}$} \\
\hline & & $\%$ & $\pm \mathrm{SD}$ & $\%$ & $\pm \mathrm{SD}$ & $\%$ & $\pm \mathrm{SD}$ & $\%$ & $\pm \mathrm{SD}$ & $\%$ & $\pm \mathrm{SD}$ \\
\hline \multirow{4}{*}{ 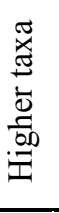 } & Polychaeta & 17.56 & 17.57 & 15.15 & 24.86 & 18.17 & 29.61 & 5.98 & 9.59 & 8.93 & 18.59 \\
\hline & Crustacea & 43.31 & 24.49 & 26.75 & 18.16 & 60.46 & 35.11 & 47.26 & 25.39 & 18.46 & 9.65 \\
\hline & Bivalvia & 0.23 & 0.40 & 0.03 & 0.10 & 0.07 & 0.17 & 0.01 & 0.03 & 0.02 & 0.05 \\
\hline & Other & 38.90 & 24.57 & 58.06 & 26.07 & 21.30 & 26.64 & 46.75 & 24.63 & 72.58 & 21.24 \\
\hline \multirow{4}{*}{$\begin{array}{l}\frac{\pi}{0} \\
\frac{\pi}{\pi} \\
\frac{0}{0} \\
\frac{2}{0} \\
0\end{array}$} & L. conchilega & 6.81 & 12.19 & 39.79 & 32.34 & 20.10 & 33.57 & 18.18 & 40.45 & 19.68 & 36.95 \\
\hline & Nereis sp. & 0.48 & 1.78 & 0 & 0 & 0.02 & 0.05 & 0 & 0 & 0 & 0 \\
\hline & E. longa & 0 & 0 & 0 & 0 & 1.01 & 3.03 & 0 & 0 & 0 & 0 \\
\hline & Other poly. & 92.71 & 12.03 & 60.21 & 32.34 & 78.88 & 33.32 & 81.82 & 40.45 & 80.32 & 36.95 \\
\hline \multirow{7}{*}{ 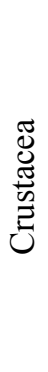 } & Crab sp. & 4.60 & 5.86 & 5.12 & 7.25 & 32.84 & 34.00 & 18.10 & 18.13 & 10.06 & 17.18 \\
\hline & Amphipoda sp. & 0.81 & 1.36 & 1.30 & 2.34 & 6.25 & 19.06 & 0.46 & 0.93 & 5.69 & 10.23 \\
\hline & Ostracoda sp. & 9.18 & 15.06 & 13.36 & 17.84 & 15.81 & 19.30 & 8.17 & 22.37 & 9.15 & 13.90 \\
\hline & Isopoda sp. & 0 & 0 & 0 & 0 & 0.83 & 2.74 & 0 & 0 & 0.71 & 2.67 \\
\hline & Cumacea sp. & 0 & 0 & 0 & 0 & 0.001 & 0.003 & 0 & 0 & 0.71 & 2.67 \\
\hline & Copepoda sp. & 0 & 0 & 0.92 & 2.90 & 0 & 0 & 0.41 & 0.78 & 1.64 & 3.56 \\
\hline & Other crust. & 85.40 & 19.00 & 79.30 & 18.51 & 44.26 & 28.28 & 72.86 & 25.66 & 72.04 & 23.76 \\
\hline \multirow{9}{*}{ 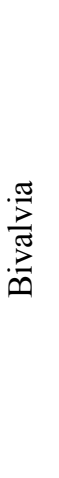 } & A. alba & 0 & 0 & 50.00 & 70.71 & 0 & 0 & 50.00 & 70.71 & 25.00 & 50.00 \\
\hline & A. opercularis & 0 & 0 & 0 & 0 & 2.86 & 6.39 & 0 & 0 & 0 & 0 \\
\hline & C. edule & 0 & 0 & 0 & 0 & 49.52 & 47.57 & 50.00 & 70.71 & 0 & 0 \\
\hline & M. balthica & 34.50 & 44.17 & 0 & 0 & 2.86 & 6.39 & 0 & 0 & 0 & 0 \\
\hline & M. bidentata & 0 & 0 & 0 & 0 & 0 & 0 & 0 & 0 & 25.00 & 50.00 \\
\hline & Nucula sp. & 0 & 0 & 50.00 & 70.71 & 0 & 0 & 0 & 0 & 0 & 0 \\
\hline & S. plana & 0 & 0 & 0 & 0 & 0 & 0 & 0 & 0 & 25.00 & 50.00 \\
\hline & S. subtruncata & 0 & 0 & 0 & 0 & 18.10 & 26.17 & 0 & 0 & 0 & 0 \\
\hline & Other bivalves & 65.50 & 44.17 & 0 & 0 & 26.67 & 43.46 & 0 & 0 & 25.00 & 50.00 \\
\hline
\end{tabular}


Table 4 Global p-values (GLM) and adjusted p-values of the pairwise tests (Tukey-Kramer) to check differences in the relative abundances of higher taxonomic groups among the five investigated waders. In case of significant differences $(p<0.05) \mathrm{p}$-values are in bold. $\mathrm{D}=$ Dunlin, $\mathrm{O}=$ Oystercatcher, $\mathrm{C}=$ Curlew, $\mathrm{G}=$ Grey Plover, $\mathrm{B}=$ Bar-tailed Godwit

\begin{tabular}{lccccccccccc}
\hline & Global & D - O & D - C & D - G & D - B & O - C & O - G & O - B & C - G & C - B & G - B \\
\hline Polychaetes & $\mathbf{0 . 0 2 5 4}$ & 0.509 & 1.000 & 0.951 & 0.398 & 0.197 & 0.242 & 1.000 & 0.894 & 0.095 & 0.183 \\
Crustaceans & $<\mathbf{0 . 0 0 0 1}$ & 0.100 & 0.531 & 1.000 & 0.069 & $\mathbf{0 . 0 0 1 0}$ & 0.124 & 1.000 & 0.354 & $<\mathbf{0 . 0 0 1}$ & 0.087 \\
Bivalves & $\mathbf{0 . 0 0 1 3}$ & 0.307 & $\mathbf{0 . 0 0 4}$ & 0.294 & 0.182 & 0.999 & 1.000 & 0.994 & 0.998 & 0.999 & 0.992 \\
Other & $\mathbf{0 . 0 0 0 9}$ & 0.833 & 0.063 & 0.894 & 0.898 & $\mathbf{0 . 0 0 2}$ & 1.000 & 1.000 & $\mathbf{0 . 0 0 2}$ & $\mathbf{0 . 0 0 2}$ & 1.000 \\
\hline
\end{tabular}


Table 5 Global p-values (GLM) and adjusted p-values of the pairwise tests (Tukey-Kramer) to check differences in the relative abundances of lower taxonomic groups (Lanice conchilega, Other polychaetes, Crabs and Other crustaceans) among the five investigated wader species. In case of significant differences $(\mathrm{p}<0.05) \mathrm{p}$-values are in bold. $\mathrm{D}=$ Dunlin, $\mathrm{O}=$ Oystercatcher, $\mathrm{C}=\mathrm{Curlew}$, $\mathrm{G}=$ Grey Plover, $\mathrm{B}=$ Bar-tailed Godwit

\begin{tabular}{lccccccccccc}
\hline & Global & D - O & D - C & D - G & D - B & O - C & O - G & O - B & C - G & C - B & G - B \\
\hline L. conch. & $<\mathbf{0 . 0 0 0 1}$ & $\mathbf{0 . 0 3 9}$ & 1.000 & 0.997 & $\mathbf{0 . 0 2 3}$ & $\mathbf{0 . 0 0 0 3}$ & 0.675 & 0.992 & 0.997 & $\mathbf{0 . 0 0 0 3}$ & 0.607 \\
Other poly. & $<\mathbf{0 . 0 0 0 1}$ & $\mathbf{0 . 0 3 6}$ & 1.000 & 0.997 & $\mathbf{0 . 0 2 2}$ & $\mathbf{0 . 0 0 0 3}$ & 0.672 & 0.992 & 0.996 & $\mathbf{0 . 0 0 0 3}$ & 0.604 \\
Crab & $\mathbf{0 . 0 0 5}$ & 1.000 & 0.070 & 0.769 & 1.000 & 0.570 & 0.950 & 1.000 & 0.135 & 0.468 & 0.950 \\
Other crust. & $<\mathbf{0 . 0 0 0 1}$ & 0.830 & $\mathbf{0 . 0 0 0 1}$ & 0.704 & 0.896 & 0.094 & 1.000 & 1.000 & $\mathbf{0 . 0 0 0 2}$ & $\mathbf{0 . 0 4 5}$ & 1.000 \\
\hline
\end{tabular}

